Dorota Lis-Staranowicz, Dr. hab.

University of Warmia and Mazury in Olsztyn, Poland

\title{
THE RELATION BETWEEN POLITICAL RIGHTS AND SOCIAL RIGHTS: SOME REMARKS CONCERNING THE POLISH CONSTITUTIONAL AND POLITICAL PRACTICE
}

\begin{abstract}
Summary
The purpose of the current paper is to address two questions. Firstly, whether and how political rights and freedoms affect the extent and content of social rights. Secondly, whether and how social rights impact an active enjoyment of political rights by citizens. It has been established that social rights are an expression of public morality and demonstrate the state's sensitivity to the needs of the disadvantaged, and that political rights are a sine qua non condition for exercising sovereign power by the nation. Political rights are intended to vindicate natural social rights from the state and to defend constitutional social rights at a level higher than the minimum. In turn, the absence of social rights or their inadequacy prompts citizens to exercise political rights and freedoms that serve to express dissatisfaction with the policies adopted by the state. It has also been established that unemployment and, consequently, poverty (insufficient protection of natural social rights) affects citizens' electoral activity and the voter turnout rate, and hence, the exercise of the right to vote, fundamental to democracy.
\end{abstract}

Keywords: social rights, political rights, social minimum, constitutional court, right to vote, turnout

\section{Introduction}

My article has neither a dogmatic nor an axiological dimension ${ }^{1}$. It is a description of a relationship between political and social rights in Poland, based on constitutional observation and political practice in recent years. The objective here is to address two questions. Firstly, whether and how political rights and freedoms

\footnotetext{
See Sokolewicz. W., Wotyczek K. Wolności i prawa polityczne. In: Konstytucja Rzeczypospolitej Polskiej. Komentarz. Garlicki L., Zubik M. (eds.), Warszawa: Wydawnictwo Sejmowe, 2016, pp. 308-324; Granat M. Dylematy konstytucyjnej zasady wolności człowieka. In: Mini-komentarz dla Maksiprofesora. Księga jubileuszowa profesora Leszka Garlickiego, ed. Zubik M. Warszawa: Wydawnictwo Sejmowe, 2017, pp. 246-261; Zubik M. Wolnośća prawo (pięć hipotez o stosowaniu pojęć konstytucyjnych dotyczących praw człowieka). Państwo i Prawo, No. 9, 2015, pp. 3-9; Sokalska E. Human Rights from Historical and Philosophical Perspective (the Outline). In L'udské Práva Včeraa Dnes. Pôvoda Význam L’udských Práva Ich Ochrana v Právnej Terminológiia Praxi (Zbornik je súhrnom príspevkov z III. ročnika medzinárodnej vedeckej konferencie "Banskobystrická škola právnych dejín", konanej v dňoch 15.-16. marca 2017 na pôdle Právnickej fakulty Univerzity Mateja Bela v Banskej Bystrici), Skaloš M., Turošík M. (eds.), Banska Bystrica: Belianum, 2017, pp. 394-406.
} 
impact the extent and content of social rights. Secondly, whether and how social rights impact an active enjoyment of political rights by citizens.

\section{Preliminary assumptions}

The starting point for further analysis is the four preliminary assumptions that outline the background of an analysis of constitutional and political practice. They refer to the provisions of the Constitution of 2 April 1997, as well as the constitutional practice forged by the case law of the Constitutional Tribunal'2.

Firstly, the Constitution of 2 April 1997 guarantees citizens a comprehensive catalogue of political rights and freedoms, which have been continuously reinforced since 1989, thus since the Polish nation's regained the ability of self-determination. The catalogue of those rights and freedoms includes: a) the freedom of association, b) the freedom of association in trade unions, c) the right to participate in a referendum and the right to vote, d) the freedom of peaceful assembly, e) the right to submit petitions, f) the freedom of speech. Political rights and freedoms define the attitude of citizens towards the state and its institutions, since they render it possible, among other things, to elect representatives to the Sejm and Senate, local government bodies, to formulate opinions and present them to public administration authorities, control and criticize public authorities, to submit draft laws to Parliament, to take decisions on important matters by referendum. They are of vital importance, since they are necessary to exercise the sovereign power by the Nation (pursuant to Article 4 of the Constitution, the supreme power is vested in the Nation. The Nation is construed, according to the preamble to the Constitution, as all citizens.)

Secondly, on the one hand, the Constitution of 1997 does not qualify Poland as a social welfare state such as Germany, Romania or Slovenia. However, Poland is a state applying the principle of social justice ${ }^{3}$. It should also be pointed out that the Constitution of 1997 was founded on the ruins of a socialist state, which protected its citizens against poverty, albeit only in theory. The fathers of the Polish Constitution, born and raised in the previous political system, felt a strong attachment to the social rights featured in the Socialist Constitution of 22 July $1952 .{ }^{4}$ Therefore, they introduced these into the text of the Constitution. The catalogue of social rights is very extensive and includes, for example, a) the right to safe and hygienic conditions of work, b) the right to statutorily specified days free from work

2 The Constitution of the Republic of Poland of $2^{\text {nd }}$ April, 1997, as published in Dziennik Set, No. 78, item 483. English text of Constitution. Available at: https://www.sejm.gov.pl/prawo/konst/ angielski/kon1.htm [last viewed October 10, 2019].

3 "The distribution of justice, sometimes referred to as social justice, concerns the powers of individuals in relation to a group of which individuals are part. In order for people to bring something to the community, they must also receive something from it." see Maryniarczyk A. O właściwą miarę sprawiedliwego działania. In: Sprawiedliwość - ideea rzeczywistość, Jaroszyński P., Krąpiec A. (eds.), Lublin: Fundacja “Lubelska Szkoła Filozofii Chrześcijańskiej”, 2009, p. 355.

4 Granat M. Konstytucja RP na tle osiągnięć konstytucjonalizmu polskiego. Przegląd Sejmowy, No. 4, 2007, pp. 14-19. 
c) the right to social security, d) the right to health care services, financed from public funds, e) the right of families, finding themselves in difficult material and social circumstances - particularly those with many children or a single parent - to special assistance from public authorities, $\mathrm{f}$ ) education financed from public funds ${ }^{5}$. I believe that social rights and, more broadly, social benefits, determine the state's attitude towards citizens who find themselves in a difficult life situation. They are the expression of public morality ${ }^{6}$ and an expression of the state's sensitivity to the needs of the poor, sick, old and lonely people ${ }^{7}$.

Thirdly, the abovementioned social rights sound optimistic and may create a sense of social security in Poland. This supposition, however, was not confirmed by statistical data, since in 1997 the rate of unemployment in Poland reached $13 \%$ and increased up to $20 \%$ in 2004. In turn, the rate of extreme poverty equalled $5.4 \%$ and increased steadily to reach $12.5 \%$ in 2005. Most Poles who found themselves in a difficult financial situation caused by the transformation of the economy, longed for a job, decent remuneration and housing. If we translate those longings into legal language, Poles demanded the right to work, the right to decent remuneration and the right to shelter, not guaranteed by the Constitution. Although those rights were not and are not subject to constitutional protection, they are not devoid of significance, as they are attached to the so-called human dignity ${ }^{8}$. Such a state of affairs is the reason why I refer to the right to work, the right to decent remuneration and the right to housing as natural social rights.

To conclude the question of social regulations in the Constitution of 1997, it should be pointed out that in addition to social rights, the legislator introduced the so-called social policy principles, which also require the authorities of the state

5 The Constitution of the Republic of Poland of $2^{\text {nd }}$ April, 1997, as published in Dziennik Ustaw, No. 78, item 483. English text of Constitution [online] https://www.sejm.gov.pl/prawo/konst/ angielski/kon1.htm. More in Garlicki L. Wolności i prawa ekonomiczne, socjalne i kulturalne. In: Konstytucja Rzeczypospolitej Polskiej. Komentarz, Garlicki L., Zubik M. (eds.), Warszawa: Wydawnictwo Sejmowe, 2016, pp. 563-569; Bułajewski S., Dąbrowski M. Wolności i prawa ekonomiczne, socjalne i kulturalne. In: Wolności i prawa człowieka w Konstytucji Rzeczypospolitej Polskiej, Chmaj M. (ed.), Warszawa: Wolters Kluwers, 2008, pp. 151-198.

6 "The Encyclical Rerum novarum of Leo XIII (Latin for new things or arrival of a new era) is one of the most important documents on political and social issues. Prior to its publication, the Pope issued about five other encyclicals on political, social and economic problems. The author thus established the basis for the development of Catholic social teaching as a science. The main problems addressed by the encyclical are the workers' issue, but also poverty and poor social status of the population due to the capitalism. Leo XIII calls for the state intervention in the economy, particularly in protecting the helpless and those in need" - Jáger R. Social and legal interaction. Banská Bystrica: Belianum, 2016, p. 86.

7 Kalisz A. Prawa socjalne w systemie prawnym oraz znaczenie w społeczeństwie. Filozofia Publiczna i Edukacja Demokratyczna, No. 1, 2014, pp. 77-102; Danowska-Prokop E. Narodziny prawa socjalnego. Nierówności Spotecznea Wzrost Gospodarczy, No. 51, 2017, p. 134.

8 Bosek L. Komentarz do Art. 30 Konstytucji Rzeczypospolitej Polskiej. In: Konstytucja RP Tom 1 Komentarz do Art. 1-86, Safjan M., Bosek L. (eds.), Warszawa: C.H. Beck, 2016; Granat M. Godność czlowieka z Art. 30 Konstytucji RP jako wartość i jako norma prawna. Państwo i Prawo, No. 8, 2014, pp. 3-22. 
to adopt a policy reducing unemployment ${ }^{9}$ and an appropriate housing policy ${ }^{10}$. However, they are not a source of subjective rights ${ }^{11}$. Moreover, the Constitution guarantees the right to minimum wages, although "there is no constitutional requirement for the amount of remuneration to correspond to the amount and quality of work"12.

Fourthly, the Constitutional Tribunal (hereinafter: CT) protects the Constitution and protects the Constitutional rights and freedoms, including social rights. However, the ability of asserting social rights before the $\mathrm{CT}$ is quite severely limited. The court adopts a conservative attitude since: (a) social rights and programmatic provisions may only be asserted before the CT to a minimum extent, as it is the responsibility of the state to ensurea minimum (social) standard of living and thus to satisfy fundamental existential needs (cf. CT judgments of 8 June 2010, file ref. No. SK 37/09; 25 February 2014, file ref. No. SK 18/13); (b) the legislator determines (acting in the framework of values and constitutional principles) "an existential threshold corresponding to the minimum level of human consumption needs under given socio-economic conditions" (see: CT judgment of 12 April 2011, file ref. No. SK 62/08); c) it is impossible to derive the right to a specific social benefit of a specific amount from the constitutional regulation of social rights; (d) when assessing cases with the social component, the CT deems it necessary to preserve the budgetary balance, which also stems from the Constitution, since the exercise of social rights generates considerable costs, and, moreover, such costs are continuously increasing; (e) the Constitutional Tribunal does not intervene if social rights are ensured at the minimum level; (f) natural social rights are not subject to CT's protection because they are not protected by the Constitution, although the Court has held that eviction onto the streets is inadmissible in the light of the human dignity principle ${ }^{13}$.

\section{How political rights and freedoms affect social rights}

The above arrangements allow to formulate two questions. Firstly, are there any legal instruments that let citizens vindicate natural social rights from the state? Secondly, are there any legal instruments that permit the citizens to vindicate constitutional social rights above the minimum level?

\footnotetext{
9 "Public authorities shall pursue policies conducive to satisfying the housing needs of citizens, in particular combating homelessness, promoting the development of low-income housing and supporting activities aimed at acquisition of a home by each citizen" (Art. 75.1 Constitution).

10 "Public authorities shall pursue policies conducive to satisfying the housing needs of citizens, in particular combating homelessness, promoting the development of low-income housing and supporting activities aimed at acquisition of a home by each citizen" (Art. 75.1 Constitution).

11 Bernaczyk M. Konstytucyjne obowiązki państwa do podejmowania działań w zakresie zaspokajania potrzeb mieszkaniowych jednostki. In: Realizacja i ochrona konstytucyjnych wolności i praw jednostki w polskim porząaku prawnym, Jabłoński M. (ed.), Wrocław, 2014, pp. 755-772.

12 Kuczma P. Prawa pracownicze. In: Realizacja i ochrona konstytucyjnych wolności i praw jednostki w polskim porządku prawnym, Jabłoński M. (ed.), Wrocław, 2014, p. 565.

13 Constitutional Tribunal judgment of 18 October 2017, file ref. No. K 27/15.
} 
Such instruments are political rights and freedoms that play an important role in asserting social rights. In my opinion, the freedom of assembly, the right to strike, the right to petition, the freedom of speech are used to articulate social demands. They are tools for exercising pressure on the government, parliament, political parties and other institutions responsible for social policy ${ }^{14}$.

The aforementioned supposition is confirmed by systemic practice. Social movements were and are active all over the world (e.g. the yellow vests protest in France; the movement of the outraged in the USA), and Poland is not an exception. Polish teachers announced a strike in April 2019, and it was the largest social protest in the history of Polish education. They demanded an increase of salaries (PLN $1000)$ as well as improved working conditions. That movement was initially widely supported by society. However, children having to remain at home and parents forced to organize the corresponding care divided the public opinion ${ }^{15}$. In the face of declining public support and loss of remuneration for the non-working time, which resulted in many teachers being left with no means of subsistence, the trade unions suspended the strike. Eventually, the strikers received a slight increase of salaries. In turn, police officers who do not have the right to strike received a high increase (PLN 1 000). A difficult social situation forced them to a different form of protest, namely, a few days before the national holiday, 30000 police officers fell ill with flu, which directly threatened public order and the internal security of the state ${ }^{16}$. The illness spread quite quickly, and the ill police officers received extensive social support $(74 \%$ of the population have a favourable opinion of police officers in Poland). These circumstances exerted pressure on the government, which met the demands of police officers ${ }^{17}$. Another type of protest was used by people with disabilities, who also do not exercise their right to strike, since most of them are not employed. In order to exert pressure on the government and the parliament, as well as to draw attention to their difficult social situation, they organized a permanent assembly in the parliament building, occupying it for 40 days. Strong public support and justified demands for social rights had an impact on the position of the government, which initially adopted a rigid approach only to finally accept some of the demands of people with disabilities ${ }^{18}$. Ultimately, the parliament passed

14 In the doctrine of the law it is argued that neither the breadth nor the depth of the constitutional regulation of social rights proves the "social" nature of the state. They are states without a constitutional regulation of social rights, emboding the protection of citizens in a difficult life situation. See Jagielski M. Constitutional regulation of social and economic matter (theoretical aspects). Gdansk Law Studies, Vol. XXXI, 2014, pp. 589-602.

15 Tomaszewicz Z. Teachers will not be happy. There is a new poll - Poles say what they think about their protest. Available at: https://natemat.pl/270193,czy-polacy-popieraja-strajk-nauczycieli-jestnowy-sondaz-kantar [last viewed October 13, 2019].

16 Matłacz A. Police officers ended the protest. They fought earlier pensions and full overtime. Available at: https://www.prawo.pl/kadry/koniec-protestu-policjantow-ze-zwolnieniamichorobowymi,326560.html [last viewed October 12, 2019].

17 Parents of disabled children occupy the Sejm. Gazeta Prawna. Pl. Available at: https:// www.gazetaprawna.pl/artykuly/785566,rodzice-niepelnosprawnych-dzieci-okupuja-sejm.html [last viewed October 12, 2019].

18 Ibid. 
the Solidarity Fund Act, imposing a solidarity tax on the highest-earning Poles. Thereby, the government found resources to finance social benefits for the disabled.

The three different social movements outlined above lead to the following conclusions. First of all, political rights are intended to pursue natural social rights and constitutional social rights from the state at a level above the minimum. Moreover, some political rights are effective if they are exercised collectively. Besides, the power of some political rights depends on the power of the social group demanding social benefits. Finally, the power of political rights also depends on the power of public support. The more citizens support social demands, the greater the chance of success.

\section{How social rights affect political rights and freedoms}

The relation of political rights and freedoms to social rights was outlined above. The question arises as to whether social rights can affect political rights and freedoms and the intensity with which they are exercised by citizens.

Firstly, an inadequate social policy of the state triggers the citizens' need to contest the actions of the government. To this end, they exercise political rights and freedoms, advancing demands, criticizing public authorities, organizing protests and strikes. By means of political rights and freedoms, citizens express their objection to the government and the social policy it follows.

Secondly, social rights or social benefits are "used" by political parties in the election game. Social policy and social promises are an important element of electoral campaigns. They are also among the decisive factors for an electoral success. In addition, promises of social benefits also provide incentives for citizens to participate in elections. Thus, for example, in the parliamentary elections of 2015 the two major political parties made promises of a social nature. Among other things, the voters were tempted by cheap housing for the young, lower retirement age for women (60), cheap student loans, a one-time allowance for young workers in the amount of PLN 4 000, a monthly allowance for the second and subsequent child in a family - PLN 500. As a result, the elections were won by a party whose political agenda was based on extensive social support for families with children and for the elderly, while voter turnout increased slightly from $48.92 \%$ in 2011 to $50.92 \%$ in $2015^{19}$. Yet, the European Parliament elections held in May 2019 are an interesting example. It was the first time that political parties made quite extensive promises of social benefits in the EP elections. They were in no way related to the presence of Poland in the EU. Parties tempted voters with pledges like an additional annual bonus retirement pension, a reduction in taxes for the young, a monthly allowance of PLN 500 per child. Promises of social benefits seem to have been decisive for the electoral success of the Eurosceptic party, although as many as $91 \%$ of Polish citizens are Euroenthusiasts. In addition, a record increase in voter turnout to the EP was

19 Report on elections to the Sejm of the Republic of Poland and the Senate of the Republic of Poland held on 25 October 2015. Available at: https://parlament2015.pkw.gov.pl/pliki/1447076581_ SPRAWOZDANIE.pdf [last viewed October 12, 2019]. 
reported in Poland, from $23.83 \%$ in 2014 to $45.58 \%$ in $2019 .{ }^{20}$ The increase in voter turnout accompanied the elections to the national parliament on 13 October 2019. For the first time since 1989 (the first free elections in Poland), the turnout of voters exceeded $60 \%$. It must also be pointed out that the social factor was heavily featured in the election campaign. The promises included elimination of income tax, raising the minimum remuneration to PLN 4 000, exempting young business operators from social security contributions, PLN 5 medications or abolishing income tax on pensions. In total, the voter turnout reached $61.74 \%$, and the elections were once again won by the party offering Poles an extensive system of social benefits.

Thirdly, it is possible to notice a link between the level of natural social rights and active participation of citizens in elections.

\section{a) Parliamentary elections in 2005:}

- the lowest turnout (40.57\%);

- $\quad$ one of the highest unemployment rates (17.6\%);

- the voter turnout in the district with the highest unemployment (WarmiaMasuria, $27 \%$ unemployment) - $44 \%$;

- the voter turnout in the district with the lowest unemployment (Mazowieckie, $13.8 \%$ unemployment) - $54 \%$.

\section{b) Parliamentary elections in 2019:}

- the highest turnout $(61.74 \%)^{21}$;

- the lowest unemployment rate (5.1\%, according to International Monetary Fund - $3.5 \%$ );

- the voter turnout in the district with the highest unemployment (WarmiaMasuria, $8.6 \%$ unemployment) - 53.61\%;

- the voter turnout in the district with the lowest unemployment (Greater Poland, $2.8 \%$ unemployment) $-62.95 \%$.

The above figures indicate that the rate of unemployment directly impacts the voter turnout. $62.70 \%$ of eligible voters participated in the first free elections held on 4 June 1989, whereby the rate of unemployment reached $0.3 \%$ in early 1990, while at the end of 1990 there was a significant increase in the number of the unemployed (approximately $5 \%$ ). In the elections to the national parliament held on 13 October 2019, the highest voter turnout in over 30 years and concurrently the lowest rate of registered unemployment was recorded.

20 Information of the National Electoral Commission. Available at: https://pe2019.pkw.gov.pl/ pe2019/pl/frekwencja/pl [last viewed October 12, 2019].

21 Announcement of the National Electoral Commission of 14 October 2019 on the results of the elections to the Sejm of the Republic of Poland on 13 October 2019. Available at: https://pkw. gov.pl/pliki/1571084597_obwieszczenie_sejm.pdf [last viewed October 20, 2019]. 


\section{Conclusions}

In conclusion, it must be noted that, firstly, political rights are the cornerstone of democracy and the attitude of the state to those in need determines the standing of democracy. Social rights express public morality and are a demonstration of the state's sensitivity. Secondly, political rights are a sine qua non condition for the exercise of sovereign power by the nation. It also serves as a tool to vindicate natural social rights from the state and to assert constitutional social rights at a level above the minimum. Thirdly, the absence of social rights or their inadequacy activates citizens to exercise their political rights and freedoms, which serve to express their dissatisfaction with the state's policies. Fourthly, the rate of unemployment and, consequently, poverty (insufficient protection of natural social rights) affects the electoral activity of citizens and the rate of voter turnout, and hence the exercise of the right to vote, which is fundamental in democracy.

\section{BIBLIOGRAPHY}

\section{Literature}

1. Bernaczyk M. Konstytucyjne obowiązki państwa do podejmowania działań w zakresie zaspokajania potrzeb mieszkaniowych jednostki. In: Realizacja i ochrona konstytucyjnych wolności i praw jednostki w polskim porządku prawnym, Jabłoński M. (ed.), Wrocław, 2014.

2. Bosek L. Komentarz do Art. 30 Konstytucji Rzeczypospolitej Polskiej. In: Konstytucja RP Tom 1 Komentarz do Art. 1-86, Safjan M., Bosek L. (eds.), Warszawa: C.H. Beck, 2016.

3. Bułajewski S., Dąbrowski M. Wolności i prawa ekonomiczne, socjalne i kulturalne. In: Wolności i prawa człowieka w Konstytucji Rzeczypospolitej Polskiej, Chmaj M. (ed.), Warszawa: Wolters Kluwers, 2008.

4. Danowska-Prokop E. Narodziny prawa socjalnego. Nierówności Społecznea Wzrost Gospodarczy, No. 51, 2017.

5. Garlicki L. Wolności i prawa ekonomiczne, socjalne i kulturalne. In: Konstytucja Rzeczypospolitej Polskiej. Komentarz, Garlicki L., Zubik M. (eds.), Warszawa: Wydawnictwo Sejmowe, 2016.

6. Granat M. Dylematy konstytucyjnej zasady wolności człowieka. In: Mini-komentarz dla Maksiprofesora. Księga jubileuszowa profesora Leszka Garlickiego, Zubik M. (ed.), Warszawa: Wydawnictwo Sejmowe, 2017.

7. Granat M. Godność człowieka z Art. 30 Konstytucji RP jako wartość i jako norma prawna. Państwo i Prawo, No. 8, 2014.

8. Granat M. Konstytucja RP na tle osiągnięć konstytucjonalizmu polskiego. Przegląd Sejmowy, No. 4, 2007.

9. Jagielski M. Konstytucyjna regulacja materii społecznych i gospodarczych (aspekty teoretyczne). Gdańskie Studia Prawnicze, Vol. XXXI, 2014.

10. Jáger R. Social and legal interaction. Banská Bystrica: Belianum, 2016.

11. Kalisz A. Prawa socjalne w systemie prawnym oraz znaczenie w społeczeństwie. Filozofia Publiczna i Edukacja Demokratyczna, No. 1, 2014.

12. Kuczma P. Prawa pracownicze. In: Realizacja i ochrona konstytucyjnych wolności i praw jednostki w polskim porządku prawnym, Jabłoński M. (ed.), Wrocław, 2014. 
13. Maryniarczyk A. O właściwą miarę sprawiedliwego działania. In: Sprawiedliwość - ideea rzeczywistość, Jaroszyński P., Krąpiec A. (eds.), Lublin: Fundacja "Lubelska Szkoła Filozofii Chrześcijańskiej”, 2009.

14. Matłacz A. Policjanci zakończyli protest. Wywalczyli szybsze emerytury i pełnopłatne nadgodziny. Available at: https://www.prawo.pl/kadry/koniec-protestu-policjantow-zezwolnieniami-chorobowymi,326560.html [last viewed October 12, 2019].

15. Rodzice niepełnosprawnych dzieci okupują Sejm, Gazeta Prawna. Pl. Available at: https:// www.gazetaprawna.pl/artykuly/785566,rodzice-niepelnosprawnych-dzieci-okupuja-sejm. html [last viewed October 12, 2019].

16. Sokalska E. Human Rights from Historical and Philosophical Perspective (the Outline). In: L'udské Práva Včeraa Dnes. Pôvoda Význam L’udských Práva Ich Ochrana v Právnej Terminológiia Praxi (Zbornik je súhrnom príspevkov z III. ročnika medzinárodnej vedeckej konferencie "Banskobystrická škola právnych dejín", konanej v dňoch 15.-16. marca 2017 na pôdle Právnickej fakulty Univerzity Mateja Bela v Banskej Bystrici), Skaloš M., Turošík M. (eds.), Banska Bystrica: Belianum, 2017.

17. Sokolewicz. W, Wotyczek K. Wolności i prawa polityczne. In: Konstytucja Rzeczypospolitej Polskiej. Komentarz, Garlicki L., Zubik M. (eds.), Warszawa: Wydawnictwo Sejmowe, 2016.

18. Tomaszewicz Z., Nauczyciele nie będą zadowoleni. Jest nowy sondaż - Polacy mówią, co sądzą o ich proteście. Available at: https://natemat.pl/270193,czy-polacy-popieraja-strajknauczycieli-jest-nowy-sondaz-kantar [last viewed October 13, 2019].

19. Zubik M. Wolnośća prawo (pięć hipotez o stosowaniu pojęć konstytucyjnych dotyczących praw człowieka). Państwo i Prawo, No. 9, 2015.

\section{Legislative acts}

1. The Constitution of the Republic of Poland of $2^{\text {nd }}$ April, 1997, as published in Dziennik Ustaw No. 78, item 483. English text of Constitution Available at: https://www.sejm.gov.pl/prawo/ konst/angielski/kon1.htm [last viewed October 10, 2019].

2. Constitutional Tribunal judgment of 18 October 2017. file ref. no. K 27/15.

3. Sprawozdanie z wyborów do Sejmu RP i do Senatu RP przeprowadzonych 25 października 2015 r. Available at: https://parlament2015.pkw.gov.pl/pliki/1447076581_SPRAWOZDANIE. pdf [last viewed October 12, 2019].

4. Information of National Electoral Commission. Available at: https://pe2019.pkw.gov.pl/ pe2019/pl/frekwencja/pl [last viewed October 12, 2019].

5. Obwieszczenie Państwowej Komisji Wyborczej z dnia 14 października 2019 r. o wynikach wyborów do Sejmu Rzeczypospolitej Polskiej przeprowadzonych w dniu 13 października 2019 r. Available at: https://pkw.gov.pl/pliki/1571084597_obwieszczenie_sejm.pdf [last viewed October 20, 2019]. 